\title{
Giftedness in the students of the second cycle of childhood education. Intervention strategies in the classroom
}

DOI: $10.46932 / \mathrm{sjjdv2n1-015}$

Received in: November 1st, 2020

Accepted in: December 30th, 2020

\author{
Sandra Giménez García \\ Graduada Educación Infantil \\ Instituição: RG Formación \\ Calle Rosalía de Castro, 44, 30107 Murcia \\ Alba Hernández Nicolás \\ Graduada Educación Infantil \\ Instituição: RG Formación \\ Calle Rosalía de Castro, 44, 30107 Murcia \\ Marta Garrido Cano \\ Graduada Educación Infantil \\ Instituição: RG Formación \\ Calle Rosalía de Castro, 44, 30107 Murcia \\ Jose María Rabal Alonso \\ Profesor ISEN Centro Universitario \\ Instituição: Universidad de Murcia \\ Calle Campus Universitario, 12, 30100 Murcia \\ E-mail: josemaria.rabal@um.es
}

\begin{abstract}
In the present work, the main differences between the terms high capacities, gifted, intellectual precocity, prodigy and talent will be developed. In addition, it will explain how to work with gifted students.

Likewise, different intervention strategies will be exposed in the classroom that will allow us to attend to the needs and specific characteristics of children with high capacities. To do this, a questionnaire will be presented, based on the Likert scale, which will help teachers to gradually measure whether these intervention strategies are developed in the classroom or not.
\end{abstract}

Keywords: High capacities, Early Childhood Education, strategies, classroom, students.

\section{THEORETICAL FRAMEWORK}

Today, the terms giftedness and high abilities can be understood as synonyms. Despite this, the concept of giftedness is discarded because it refers to superiority (an aspect that is not entirely real), therefore having a negative connotation. For this reason, we can affirm that the concept of giftedness has evolved from severe conceptions to other extensive and tolerant ones. 
In society, giftedness is related to intelligence. To determine intelligence, a test is carried out that gives us the IQ of a person. These tests vary according to the test that is carried out and the age of the student.

A person will be considered gifted when a score of two or more standard deviations above the mean is achieved, that is, a score of 130 or higher.

Likewise, the lack of understanding of what constitutes giftedness has led to wrong assumptions, which make the child not have a good relationship with his environment, which does not understand it, but puts pressure on him, causing emotional imbalances (Patti, Brackett, Ferrándiz and Ferrando, 2011).

The term giftedness encompasses a certain "oddity" about these children due to their abilities, skills and characteristics, leaving the child labeled as "gifted". Therefore, it is important to ask ourselves what giftedness is, which is often confused with other terms such as talented, genius, creative, or early maturation.

We consider a person as gifted when they present an advanced development in their abilities, both at school and in their day-to-day life. To this must be added that they have a high intellectual ability, greater than what they should have for their age (Babarro, 2019).

Due to the cultural differences of each country, there are numerous descriptions of what and how gifted children are. In Spain, the most popular concept is giftedness, although the Ministry of Education and Science has decided to refer to them as subjects with specific educational needs associated with intellectual giftedness. This has caused terminological confusion (Peñas, 2006), so we will now proceed to explain each of the concepts.

\subsection{CONCEPTUAL CLARIFICATION}

\section{* High capacities}

In the specialized literature, there is usually no difference in the use of the concepts gifted and high capacities, since it is understood that there are no major differences between them. High capacities, it is usually used as a synonym for gifted (Peñas, 2006) and, in addition, it includes the terms talented, prodigy and precocious, although there are differences between them (Albes et al., 2013).

The LOE introduces the term of high abilities and, although it does not define it, it has been accepted since it is a more general term than giftedness. In addition, it also refers to talents, precocious and all those students who have behaviors typical of a well-gifted child. When speaking of high abilities, it is essential to refer to their potential character, in the face of the performance requirement, which is collected by other terms as well as by previous educational legislation (Comes, Díaz, Luque and Moliner, 2008, p.105). 


\section{* Gifted}

As stated by Albes et al. (2013): "the cognitive configuration of giftedness is characterized by the combination of all intellectual resources, which enables a high level of efficiency in any form of information processing and management" (p.11). The author states that gifted people have a good memory, high attention and concentration capacity, cognitive flexibility, ease in dealing with new situations, ease in adapting to changes, among others.

To these characteristics, we must add the following: high capacities, exceptional performance, a high capacity for memorizing and learning, curiosity, originality, creativity, perfectionism and detail (Babarro, 2019).

Referring to Babarro (2019), we differentiate two types of giftedness:

- $\quad$ Giftedness related to high IQ (academic abilities).

- Giftedness linked to creativity.

\section{* Talent}

According to Albes et al. (2013), talents have: "High performance in one or more specific areas. They can present a high capacity in one area, cognitive aspect or type of processing and, nevertheless, show a medium or even low performance in other areas or dimensions "(p.12). As Acereda (2000 cited in Peñas, 2006) states:

A first difference with respect to the gifted would be that, while the gifted has a cognitive structure and information processing capacities adaptable to any content, the talented has a combination of cognitive elements that make him especially suitable for a certain dynamic. (p. 36).

We can differentiate several types of talents. Following Castelló and Battle (1998, cited in Albes et al., 2013), we distinguish between:

-Simple and multiple talents: mathematical, logical, social, creative, verbal.

-Complex talents: academic and artistic-figurative.

\section{* Prodigy}

The prodigy concept, according to Peñas (2006), includes all those people who: "Show exceptional performance or performance for their age in a specific area (art, music, physics, literature, etc.)" (p. 27). Similarly, the author makes a distinction between talented and prodigy. For her, talent refers to an outstanding attitude in one or more subjects in which the person has a high performance. On the contrary, prodigy, refers to a person who has an extraordinary performance given their chronological age in an area or subject. This means that the prodigy, in addition to having an excellent performance, also "" does so at 
an age at an age in which evolutionarily it is not expected, which would not happen with the only talented person "(Peñas, 2006, p. 28).

\section{* Intellectual precocity}

As stated by Albes et al. (2013): "We are dealing with precocious students when they show greater evolutionary development at an earlier age than children of the same chronological age. They may also acquire knowledge or demonstrate skills earlier than expected for their age "(p. 12). It is important to distinguish between a precocious child and a prodigy. Therefore, Peñas (2006) states that:

The precocious child shows an earlier development of some of the learning and achievements related to the various developmental stages (speech development, gait establishment, beginning of reading, etc.). On the contrary, the prodigy equates and on many occasions exceeds the performance of adulthood in a specific domain of human knowledge. The key in this case is exceptional performance. (p. 27).

Despite this, in the case of precocious children, it is essential to recognize other characteristics in order to speak of giftedness. That is to say, it is not enough for superior skills to appear early to be able to speak of giftedness, since later they end up developing the same as other children of their age, thus making early precocity disappear (Peñas, 2006).

Therefore, we can affirm that two fundamental characteristics of these children are creativity and abstract thoughts. Likewise, they tend to observe and critically analyze, have leadership skills, a varied vocabulary, high originality, and find unusual topics attractive.

In addition, they present some peculiarities such as their intellectual capacity, a good academic attitude, a productive and creative thinking, a penchant for the plastic arts and a high psychomotor ability (Jiménez, 2009).

In one of the conclusions of the World Conference on "Special Educational Needs. Access and quality "(UNESCO, 1994, p.59), it is stated that:

The guiding principle of this framework is that schools must take all children, regardless of their physical, intellectual, social, emotional, linguistic or other conditions ... They must take disabled children and well-gifted children ...

These changes have helped the educational system to become an equitable, quality and equal education for all students. For this reason, Spanish legislation includes the Laws of Education, where the need is manifested for students with high abilities to obtain specific educational attention from the educational administrations. 
As stated in Article 72 of LOMCE 8/2013, of December 9, for the improvement of educational quality, and whose thesis is extended to the Organic Law that Modifies the Organic Law of Education (LOMLOE), "corresponds to the Educational administrations adopt the necessary measures to identify students with high intellectual capacities and assess their needs early".

Despite this, according to recent statistics from the Ministry of Education and Vocational Training, most of the students are not obtaining an education adapted to their needs, since it barely exceeds $0.42 \%$ of students with high abilities.

\subsection{HOW TO WORK WITH STUDENTS WITH HIGH SKILLS?}

To find out, it is essential to know what your needs are. First, it is important to accept the student as he is, thus accepting his successes and mistakes. We will therefore deal with their cognitive, social and emotional needs as well as positive self-concept, knowing both their strengths and weaknesses. In the same way, we will help the student to know himself, showing him what high abilities are and, therefore, the advantages and disadvantages that it entails. We will understand your enthusiasm for learning, as well as your high curiosity, without ever holding back your worries. Likewise, we will achieve a balance between the capacities and interests of the child with the demands and possibilities established by society. Also, as teachers, It is essential that we accept the need for gifted children to contribute what they know, as well as to encourage them creatively and intellectually. Finally, it is essential to offer the student opportunities in which he can interact with other children with whom he shares the same interests (Albes et al. 2013).

\section{INTERVENTION STRATEGIES IN THE CLASSROOM}

With regard to the strategies or techniques that can be used for the comprehensive development of children with high abilities, in accordance with current regulations, Organic Law 8/2013, of December 9, for the improvement of educational quality, we says that it is up to the educational administrations to adopt action plans, enrichment and extension programs appropriate to the needs of gifted students so that they can develop their abilities to the maximum.

On the other hand, it is essential in schools to improve the attention of gifted students, from an inclusive approach that takes into account a response adjusted to their specific characteristics. Therefore, a very useful strategy in the classroom is cooperative learning, which is a very successful methodological strategy to provide quality care to these students within a normalized and inclusive context. Cooperative learning is one of the various ways of structuring the training activities carried out in the teaching-learning process (Torrego, Monge, Pedrajas \& Martínez, 2015). According to Vygotsky (1979, cited in Torrego, 
Monge, Pedrajas and Martínez, 2015), knowledge is formed in social contexts through processes of conversation with others. As these authors state:

Another intervention strategy, as previously mentioned, would be enrichment programs, but based on Howard Gardner's Multiple Intelligences. These programs offer students to delve into a concept or a specific area to a greater extent than the ordinary curriculum and, of course, the day-to-day life in the classroom allows (Carpintero, Cabezas \& Pérez, 2009). Following these authors, the main objective of enrichment programs is not only curricular expansion, but also psychological intervention in different areas of development: social, affective and emotional. In this sense, there are some communities in Spain -Murcia among others - that implement, as a measure of intervention and care for students under this diagnosis, enrichment workshops.

In this sense, these authors propose an enrichment program from the perspective of Multiple Intelligences, which "clearly deals with a curricular model built around the concept of multidimensionality of intelligence, considering this as the ability to solve problems and create products culturally valued "(Gardner, 1983, cited in Carpintero, Cabezas and Pérez, 2009, p.5). Likewise, these authors tell us about a didactic and simple model that takes into account socially recognized characteristics and aptitudes, that is, it consists of recognizing intelligence both related to the curricular product and in a parallel way to it, due to the diversity of intelligences that it describes, allows adaptation to all existing curricular areas, as well as to the diverse talents of the students.

Regarding the organization of the classroom, this would be another intervention strategy, since the environment in which the student with high abilities learns will favor their teaching-learning process and will lead to the student feeling comfortable, stimulated and motivated while learning. In this way, according to Pérez and Jiménez (2018), the environment must be rich and stimulating, the schedules, groups and teaching style open and flexible, the activities adapted to their level and that pose a challenge (Carpintero, Cabezas and Pérez, 2009), extensive and rich didactic resources. They also need to enhance their abstract and creative thinking (Carpintero, Cabezas \& Pérez, 2009).

Therefore, we have to be prepared to deal with different learning paces. As we mentioned earlier, the characteristics of children with high capacities, generally, tend to acquire knowledge faster than other children, so we must adapt the curriculum to the needs they have. For this, it will be necessary to design various educational programs that reflect the different learning rhythms.

To facilitate the inclusion of the child with high abilities in the classroom, we have three different modalities. These are the following: 


\subsection{ACCELERATION.}

This modality consists of accelerating the learning pace and, as Blanco (2001) explains, there are three ways to perform this acceleration:

a) Advance a course.

b) The admission of this student to the educational system at an earlier age than that stipulated.

c) Carry out an acceleration in the subjects adapting them to the characteristics of the student.

\subsection{GROUPINGS.}

Blanco (2001) indicates that grouping consists of uniting gifted children in groups. In this way, work programs are designed according to the level of said group.

These strategies have been considered as a form of segregation contrary to integration policies. In Spanish legislation, it is established that gifted students must be enrolled in ordinary centers and that the possibility of Special Educational Centers for them will not be admitted. On the contrary, it is in other countries such as the United States, Japan, Korea or Switzerland, where there is the possibility that children with high capacities attend specialized centers (Banús, 2014).

\subsection{ENRICHMENT.}

With this strategy, we can individualize the teaching-learning processes. It would consist of keeping them with the rest of the classmates but developing a qualitatively different curriculum that suits their needs. It is an adaptation in which the curriculum of the other colleagues should be taken into account as a starting point.

For said enrichment to be effective, it is necessary to meet three requirements: that the academic context allows individualization of learning, that it allows work with other colleagues and that activities are provided at the same time as other colleagues (Blanco, 2001).

On the other hand, as indicated by Blanco (2001), there are several ways to carry out this method:

- Curriculum expansion: content is added to the ordinary curriculum, that is, it would be the same content but with more information.

- Curriculum adaptation: we carry out a personalized educational program with greater complexity than the rest.

- Random enrichment: with this modality, the student will be able to choose topics following their own motivations and interests, in addition to working on those of the stage.

The enrichment method is the most effective and appropriate from the inclusive point of view. 
Some other proposals by Blanco (2001) could be tutoring with the student, homeschooling and individualized teaching.

On the one hand, tutorials consist of the child with high abilities being the tutor of another student. The objective of this proposal would be to adapt the level of this child to the rest of his classmates, in addition to working cooperatively and having the figure of a leader.

On the other hand, homeschooling is about home schooling, as parents are tutored by a group of professionals, who guide them on their study plans and the resources to use.

Finally, individualized teaching consists of designing a specific curriculum for the gifted child, which will be carried out within the ordinary classroom. This strategy requires a lot of work on the part of the teacher, since they must elaborate the objectives, contents and activities to be developed.

Along these lines, scientific evidence has shown that methodologies based on guided discovery and "flipped classroom "are highly effective in the intervention with these students.

\section{QUESTIONNAIRE ON STRATEGIES DEVELOPED IN THE CLASSROOM TO ATTEND HIGH CAPACITIES}

The following questionnaire is based on the Likert scale, created by the psychologist Rensis Likert in 1932. It is a method that allows us to measure the opinion that a person has on a specific topic, all through a questionnaire in which said person must indicate their degree of agreement or disagreement.

In our case, the questionnaire allows us to know if the appropriate intervention strategies are developed in the classroom to meet the specific characteristics and needs of a highly capable student. It consists of 17 items that must be answered as they always happen (4), almost always (3), sometimes (2) or never (1).

\subsection{CREATION, CONFORMATION AND VALIDATION PROCESS}

To achieve a source of information that we can trust and that enables us to obtain sufficient results, it is essential that the tool to be developed is appropriate. For this reason, the questionnaire (Alonso, Bernal, Martínez, Escolar \& Romero, M, 2020 and Alonso, Flores, Murcia \& Romero, 2020) is one of the most appropriate instruments, since it allows us the simplicity of reproduction and use, its performance as well as the results of the data obtained.

Therefore, we can affirm that we did not find a proposal before, but that in this research, a questionnaire prepared with a base will be put into practice.e theoretical and with a verification carried out by professionals. This process of validation of the questionnaire (included in the "annex" section) was based on sharing this tool with professionals active in Early Childhood Education, Primary and Secondary 
Education and university teachers. The objective was to extrapolate the results to people of any age. In addition, these teachers were asked to write down the time it took them to prepare the questionnaire, in order to confirm and verify that it is a short-term tool. Thus, the questionnaire could be carried out by many volunteers.

This is made up of various sections, one for each study developed. Delving into the procedure of this tool, it was thought through two stages. The first of these was the scrupulous bibliographic study that was developed in the face of the Emotional Intelligence variables. The second stage was the collaboration of the various educational experts.

On the other hand, as a rule to maintain an item, a methodology similar to that presented by various researchers such as Alonso, Bernal, Martínez, Escolar \& Romero, M. (2020) and Alonso, Flores, Murcia \& Romero, (2020) was followed. which consists of implanting a consonance of at least $3 / 4$ of the experts. In evaluations of five points out of three or less in two or more evaluators, this item was revised or discarded. Thanks to the choice made of the items in the questionnaire, no change or discard was made.

To conclude, all this gives us a correct result, due to its suitability, simplicity and simplicity of use in future research in order to strengthen quality teaching and look for the aspects that should be enriched.

\subsection{LIMITATIONS}

Likewise, it is essential to develop a process of final discernment, with the aim of gathering and clarifying the problems that have appeared with the completion of this research. Therefore, it is important to point out the obstacles that have arisen with the completion of this study, the purpose of which is to help future research with a similar theme.

First of all, it is essential to mention the rare situation we are in today. Due to the epidemic, the search for documents and publications for the development of research has been very limited. In addition, due to the mobility limitation measures, it has been impossible to go to specialized places in the subject studied. For this reason, we have relied on and based on electronic resources. Similarly, we have not been able to expand the information to the level we expected.

Finally, taking into account another limitation, as we are not subsidized we have not had precise and determined aid in terms of the benefit of the materials, resources and instruments to delve into the search for information. Thus, we have relied on our own knowledge of databases and significant scientific sources to be able to adapt to the appropriate approach to this research. 


\section{CONCLUSION}

It is essential to know the differences between giftedness, high capacities, prodigy, talent and intellectual precocity in order to be able to adequately attend, not only to the tastes, interests and motivations of these students, but also to their characteristics and needs. In addition, it is essential to know how to work with these students in an ordinary classroom to achieve their integral development, knowing their strengths and weaknesses, helping the student to know himself, teaching him what high abilities are, promoting his creativity, giving him the opportunity to interact with other children who have the same interests, among many other aspects to consider.

Also, another essential aspect to take into account are all those strategies that we are going to use to intervene in the classroom. Of course, as mentioned above, it is very important to adapt to the specific characteristics of these students, cooperative learning being a very useful strategy in the classroom. It is also necessary to attend to the organization of the classroom making it favor the teaching-learning process, in which the child feels comfortable and motivated, working in a rich and stimulating environment. Similarly, it is essential to attend to the different learning rhythms present in the classroom, even adapting, if necessary, the current curriculum and / or designing educational programs.

Because, as Marta Tourón stated: "Would you wear all children of the same age with shoes of the same size?" 


\section{REFERENCES}

Albes, C., Aretxaga, L., Etxebarria, I., Galende, I., Santamaría, A, Uriarte, B. y Vigo, P. (2013). Orientaciones educativas. Alumnado con altas capacidades intelectuales. Recuperado de: http://www.hezkuntza.ejgv.euskadi.net/r43-

573/es/contenidos/informacion/dig_publicaciones_innovacion/es_escu_inc/adjuntos/16_inklusibitatea_1 00/100012c_Pub_EJ_altas_capacidades_c.pdf

Babarro, N. (2019). Superdotados: definición, características, tipos y problemas. Psicología-online. Recuperado de https://www.psicologia-online.com/superdotados-definicion-caracteristicas-tipos-yproblemas-4575.html

Blanco, M.C. (2001). Guía para la identificación y seguimiento de alumnos superdotados. Bilbao: Cisspraxis.

Banús Llort, S. Intervención superdotados. http://www.psicodiagnosis.es/areaescolar/intervencionpsicopedagogica-alumnosespeciales/intervencion-psicoeducativa-en-nios-superdotados/ de Diciembre de 2014) Consultado: 14/11/2014

Carpintero, E., Cabezas, D. y Pérez, L. (2009). Inteligencias Múltiples y altas capacidades. Una propuesta de enriquecimiento basada en el modelo de Howard Gardner. Faísca,14(16), pp. 4-13. Recuperado de: https://dialnet.unirioja.es/servlet/articulo?codigo=3543229

Comes, G., Díaz, E., Luque, A. y Moliner, O. (2008). La evaluación psicopedagógica del alumnado con altas capacidades intelectuales. Revista de Educación Inclusiva, 1(1), pp. 103- 117. Recuperado de la URL: https://dialnet.unirioja.es/servlet/articulo?codigo=3011828

Jiménez, L, A.M. (2009). Niños superdotados. Innovación y experiencias educativas, (17).

Ley Orgánica 2/2006 de 3 de mayo de Educación (BOE de 4 de mayo), modificada por la Ley Orgánica 8/2013, de 9 de diciembre, de Mejora de la Calidad Educativa (BOE de 10 de diciembre).

Ley Orgánica 8/2013, de 9 de diciembre, para la mejora de la calidad educativa. BOE (Boletín Oficial del Estado), 295, de 10 de diciembre de 2013, pp. 97858- 97921

Patti, J., Brackett, M., Ferrándiz, C., y Ferrando, M. (2011). ¿Por qué y cómo mejorar la inteligencia emocional de los alumnos superdotados? Revista Electrónica Interuniversitaria de Formación del Profesorado, 14(3), 145-156.

Peñas, M. (2006). Características socioemocionales de las personas adolescentes superdotadas. Ajuste psicológico y negación de la superdotación en el concepto de sí mismas. (Tesis doctoral). Universidad Pontificia Comillas, Madrid. Recuperado de la URL: http://redined.mecd.gob.es/xmlui/handle/11162/83857

Torrego, J. C., Monge, C., Pedrajas, M. L. y Martínez, C. (2015). Formación del profesorado en aprendizaje cooperativo y alumnos con altas capacidades: un enfoque inclusivo. Revista latinoamericana de educación inclusiva, 9(2), pp. 91-110. Recuperado de: https://dialnet.unirioja.es/servlet/articulo?codigo $=5504538$ 
UNESCO / MEC (1994a) Declaración de Salamanca y Marco de Acción para las Necesidades Educativas Especiales. Aprobada por la conferencia mundial sobre necesidades educativas especiales: acceso y calidad. Salamanca, 7-10 de junio de 1994 (http://www.uneso. org/education/nfsunesco/pdf/SALAMA).

\section{ANNEXED}

\begin{tabular}{|c|c|c|c|c|}
\hline ITEMS & 1 & 2 & 3 & 4 \\
\hline \multicolumn{5}{|l|}{$\begin{array}{l}\text { The child with high capacities is cared for from an inclusive } \\
\text { approach. }\end{array}$} \\
\hline \multicolumn{5}{|l|}{ Its specific characteristics are taken into account. } \\
\hline \multicolumn{5}{|l|}{ Cooperative learning is favored. } \\
\hline \multicolumn{5}{|l|}{ The classroom is well organized. } \\
\hline \multicolumn{5}{|l|}{ The student is motivated and stimulated. } \\
\hline \multicolumn{5}{|l|}{ The atmosphere is rich and inspiring. } \\
\hline \multicolumn{5}{|l|}{ Schedules, groups, and teaching styles are open and flexible. } \\
\hline \multicolumn{5}{|l|}{ The activities are adapted to your level and are challenging. } \\
\hline \multicolumn{5}{|l|}{ The didactic resources are very extensive and rich. } \\
\hline \multicolumn{5}{|l|}{ The curriculum is adapted to your needs. } \\
\hline \multicolumn{5}{|l|}{$\begin{array}{l}\text { Educational programs have been designed to attend to the } \\
\text { different learning rhythms. }\end{array}$} \\
\hline \multicolumn{5}{|l|}{ Enrichment programs are held. } \\
\hline \multicolumn{5}{|l|}{ A curricular extension is carried out. } \\
\hline \multicolumn{5}{|l|}{ A curricular adaptation is carried out. } \\
\hline \multicolumn{5}{|l|}{ Individualized teaching is favored. } \\
\hline \multicolumn{5}{|l|}{ Homeschooling is worked on. } \\
\hline The student with high abilities works as a student-tutor. & & & & \\
\hline
\end{tabular}

